\title{
An Empirical Description of Billionaires
}

\author{
Andrew A. Anabila ${ }^{1}$ \& Eun Young Whang ${ }^{1}$ \\ ${ }^{1}$ Department of Accounting and Business Law, University of Texas-Pan American, Edinburg, Texas \\ Correspondence: Eun Young Whang, Department of Accounting and Business Law, University of Texas-Pan \\ American, Edinburg, Texas. Tel: 1-956-665-7936. E-mail: whange@utpa.edu
}

Received: March 5, 2014

Accepted: March 26, 2014

Online Published: March 28, 2014

doi:10.5430/afr.v3n2p112

URL: http://dx.doi.org/10.5430/afr.v3n2p112

\begin{abstract}
We investigate why some countries such as the U.S. have more billionaires than others. And why some countries (e.g., China, Russia, India) have turned out increasing number of billionaires in recent years whereas some others (e.g., Japan) experienced decreases. To explain this phenomenon, we use country level factors (i.e., culture, economic development, and law and order tradition) and an individual factor (i.e., education). We use six aspects of Hofstede et al.'s (2010) culture variables to examine which dimensions of culture foster billionaires. To explain billionaires' effort at the individual level, we examine the role of education in billionaires' ability to accumulate and sustain their wealth in the future. Using 11,783 individual observations from annual Forbes "The World's Billionaires List" from 1999 to 2013, we find that billionaires are bred not born: in cultures with more power distance, more individuality, less masculinity, and more long-term orientation, individuals have more chance to become billionaires and promote their wealth. In addition, the degree of individuals' education affects their ability to create wealth as well as to sustain it in the future. Our findings have supports in literature on psychology, labor economics and signaling theory.
\end{abstract}

Keywords: Culture, Billionaires, Education, Signaling theory, Marshmallow Test

\section{Introduction}

The major objective of this paper is to examine the role of culture and education on the wealth creation of billionaires, which has been questioned since the rise of the capitalism but still not fully answered. This paper uses the annual publication of "The World's Billionaires List" by Forbes. Billionaires represent the ultimate when it comes to wealth creation. They play important roles in society through the charitable activities: donating their fortune to various projects that can benefit not only those who have been in underprivileged communities but also the entire human race (Pincock, 2003, Larkin, 2006). As a result, the billionaires are becoming more influential people in the society to the extent that many of them (e.g., Bill Gates, Warren Buffet, and etc.) are listed on Forbes "The World's Most Powerful People" (Pincock, 2003, Larkin, 2006).

Total worth (in billions of U.S. \$)

Number of billionaires

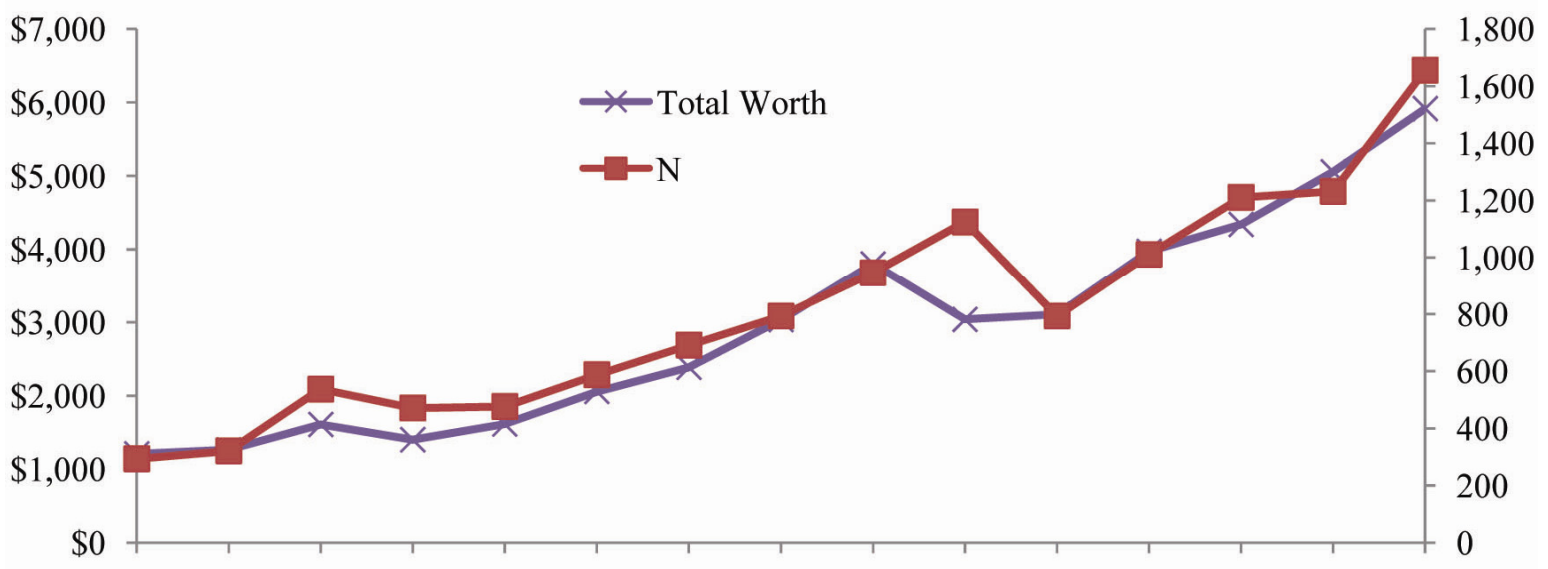

199920002001200220032004200520062007200820092010201120122013

Figure 1. Trend of total worth (in billions of U.S. dollars) and number of billionaires (N) 
According to Figure 1, the number of billionaires has more than quintupled from 1999 to 2013 (293 billionaires in 1999 and 1,656 billionaires in 2013) and their total wealth has increased about six times over the same period. Some countries (e.g., U.S.) are more successful in cultivating and creating wealth of billionaires than other countries due to the differences in societal and economic infrastructures (Tonoyan et al., 2010). Observing the differences across the countries, we pose and address our research questions using billionaires worldwide who are listed on Forbes. Because they provide a natural environment to examine the role of culture, education, and other macro variables (such as, the degree of economic development, and law and order system) in creating an enabling environment that nurtures billionaires. In addition, to explain why not all members of countries living under the same influence of social infrastructures become billionaires, we examine the individual effort to become a billionaire: the level of education. Starting with Spence (1973), there has been extensive research on the signaling theory which use the level of education of agents to proxy their ability, which is unobservable to principals. In this paper, we aim to twist the existing paradigm of signaling theory and examine the role of education as one of the determinants of level of billionaires' wealth, the self-employed principals.

Culture, a multi-dimensional and multi-leveled attribute, is formed over a relatively long period of time and is shared among its group members (Taras et al., 2009). To identify and differentiate culture of each country, we use six aspects of Hofstede et al.'s (2010) culture variables (i.e., uncertainty avoidance, power distance, individualism, masculinity, long-term orientation, and indulgence) and examine which dimensions of culture play important roles in fostering the wealth of billionaires.

The degree of economic development of a country is also one of the potential nurturing factors in breeding billionaires. In general, the GDP is used as a proxy to measure each country's degree of economic development and its capacity to produce goods and services (Gutierrez et al., 2007, Kreiser et al., 2010). Hence it reveals the country's resource availability and economic infrastructure that its citizens can utilize to create and accumulate their individual wealth. According to Forbes, U.S., the first ranked single country in terms of GDP (World Bank 2013), accounts for $41 \%$ of billionaire year observations (total of 4,831 billionaire year observations) between year 1999 and 2013, which is an outstanding number compared to other countries.

Law and order system is also one of the societal factors in nurturing billionaires. Legal system (e.g., civil law, common law, and etc.) and culture have influenced each other and have determined the level of risk avoidance and proactiveness of its members (Hitt et al., 2004). And it draws a borderline of legitimate ways to do the business for entrepreneurs (Kreiser et al., 2010, Tonoyan et al., 2010). According to Baumol's (1990) theory, the existing economic, political and legal infrastructures guide entrepreneurs to become either productive (i.e., create wealth from productive market activities) or unproductive entrepreneurs (i.e., participate in lobbying or bribing). Therefore, they set the legal boundary for their members to increase their wealth without breaking the social order.

In addition, to explain why not all members of countries living under the same influence of social infrastructure become billionaires, we examine individual effort to become a billionaire: the level of education. According to signaling theory, the level of education is used as one of the signals to reveal unobservable ability of the principal (Spence, 1973). Therefore, we examine the role of education as one of the proxies to measure billionaires' ability to create and sustain their wealth, which is unobservable to public. However, according to Forbes "The World's Billionaires List" from year 1999 to 2013, the level of education shows an increasing trend over time but getting a higher education is not directly associated with increases in their wealth. In this paper, we aim to do a comprehensive study to find out the role of education in creating and increasing the wealth of the self-employed principals, the billionaires.

Using 11,783 individual year observations listed in Forbes "The World's Billionaires List" from year 1999 to 2013, we find the total number and wealth of billionaires have been increased steadily over the sample years. We also find that culture plays an important role in creating and accumulating wealth of billionaires even after controlling for economic development and legal system. In cultures with more power distanced, more individuality, less masculinity and long-term orientation tend to create and enable billionaires to sustain their wealth. In terms of role of education, we find that billionaires with master's degrees and higher tend to increase and sustain their wealth in the future than others.

The remainder of paper is structured as following. In section 2, we review prior literature and develop hypotheses and in section 3, we explain our research methodology and describe the data and sample selection criteria. In section 4, we present our findings and in section 5, we make summary and conclusion of our results. 


\section{Literature Review and Hypotheses Development}

\subsection{Culture}

Culture is an attribute that is developed and shared by group members which distinguishes them from other group members and formed over long period of time (Hofstede, 2001). Culture influences individuals at the very early stage of life in building their values and shaping their behaviors and will influence throughout their life (Hofstede, 1980, Muller and Thomas, 2001). Prior research finds that culture is one of the major determinants in developing the latent powers which enable each individuals to become billionaires (Muller \& Thomas, 2001, Steensma et al., 2000). Wang et al. (2001) find that culture and other social contexts play important roles in forming the entrepreneurship. Because of its multi-dimensional and multi-leveled nature, there is no uniform measure to proxy culture. However, Hofstede et al. (2010) develop a culture measure with six dimensions which affect organizational behaviors of members by sampling companies that operate internationally. Taras et al. (2009) state that Hofstede et al.'s (2010) six dimensions of culture are the most widely used in the management literature to proxy culture hence, we adopt Hofsetede et al.'s (2010) six dimensions of culture; uncertainty avoidance, power distance, individualism versus collectivism, masculinity versus femininity, long-term orientation versus short-term orientation, and indulgence versus restraint (Hofstede et al., 2010).

Uncertainty avoidance indicates how members in the organization perceive ambiguity and risk (Hofstede, 1980, Hofstede, 2001, Hofstede et al., 2010). Prior studies show that in countries with high uncertainty avoidance, their members show preference for rules and regulations and feel uncomfortable with changes because they invite more risk and uncertainty (McGrath et al., 1992, Kreiser et al., 2010). Consistently, Muller and Thomas (2001) find that there are more entrepreneurial activities in countries with culture that has low uncertainty avoidance.

Power distance indicates the degree of power inequality among organizational members. Members in high power distanced organizations tend to take hierarchical structure for granted than members in low power distanced organizations (Hofstede, 1980, Hofstede, 2001, Hofstede et al., 2010). As a result, in high power distanced organizations, the hierarchical structure is more rigid that it is hard to achieve social mobility (Shane, 1995). Kreiser et al. (2010) examine small to medium sized enterprises and find that power distance has a negative impact on firms' proactiveness.

Individualism measures the degree of dependence among members in the organizations. In individualistic organizations, there will be more numbers of entrepreneurs because members tend to rely more on their own decisions than group decisions compared to those in collectivistic cultures (Hofstede, 1980, Hofstede, 2001, Hofstede et al., 2010). Morris et al. (1994) find that in cultures with individuality, entrepreneurs tend to become successful by engaging in independent activities rather than in collective or group activities. Surveying executives from 20 different countries, Geletkanycz (1997) finds that executives from cultures with high individuality tend to favor leadership and commit to status quo strategy.

In masculinity cultures, the social atmosphere is more competitive and assertive, and members value materialism, and ambition. On the other hand, in femininity cultures, they value quality of life and tend to be more cooperative and caring (Hofstede, 1980, Hofstede, 2001, Hofstede et al., 2010). McGrath et al. (1992) survey entrepreneurs and non-entrepreneurs from 9 different countries and find that entrepreneurs tend to show masculinity, individuality, and high power distanced compared to non-entrepreneurs even after controlling for their nationality. Steensma et al. (2000) find that in femininity cultures, the cooperative strategy is more acceptable than the competitive strategy.

Long-term oriented cultures put more emphasis on future, and value persistence and are more acceptable to changes. Whereas, short-term oriented cultures perceive present and past more importantly than future and tend to value tradition (Hofstede et al., 2010). Long-term orientation can be linked to one of the well-known theory in psychology: marshmallow test. Marshmallow test is based on the serial of follow-up studies and find that nursery school students who are willing to wait for an extra treat tend to exhibit better school and work performance, and tend to be healthier and better at keeping the relationship as they age (Mischel, 1958, Mischel et al., 1972). Geletkanycz (1997) finds that managers in long-term oriented cultures tend to be better in adapting to environmental changes and be open to revising their existing strategy if it is necessary to achieve a success.

The degree of indulgence indicates the acceptance for enjoying and having fun in life whereas, restraint indicates suppressing the desire and pleasure and following norms and standards (Hofstede et al., 2010). Indulgence versus restraint is also linked with marshmallow test by Mischel (1958) and Mischel et al. (1972) that members in restrained culture are more likely to sacrifice their current pleasure to achieve a goal in the future.

Based on the foregoing, we state our first hypothesis on relation between culture and wealth creation of billionaires 
in a null form.

HO 1: Billionaires'wealth is not associated with six dimensions of culture.

\subsection{Education}

The ability of billionaires is unobservable to others (Spence, 1973, Akerlof, 1970). However, billionaires do not face a great amount of agency cost nor the information asymmetry problems because they are the principals for their wealth. But to measure their individual ability as a billionaire, we consider level of education (Becker, 1964). Muller and Thomas (2001) find business related educations, such as accounting, marketing, finance, and management equip individuals to become successful entrepreneurs. Some studies find that existing education system prevents creative minds to explore new opportunities to create wealth (Budman, 1997, Vance et al., 2012).

It is also reflected in Forbes' billionaires list: there are numbers of billionaires who are able to make top in the rank but don't finish university education. For example, both Bill Gates in Microsoft ( $\$ 67$ billion ranked $2^{\text {nd }}$ in Forbes 2013 billionaires list) and Larry Ellison in Oracle ( $\$ 43$ billion ranked $5^{\text {th }}$ in Forbes 2013 billionaires list) are known as successful billionaires who self-made their wealth after dropping out from college. This is not restricted to U.S. billionaires but can be found in other countries as well. Li Ka-Shing ( $\$ 31$ billion ranked $8^{\text {th }}$ in Forbes 2013 billionaires list), a Hong-Kong billionaire, is a high school dropout but self-made his fortune from Hutchison Whampoa Limited, an investment holding company. These cases cannot be generalized to all billionaires in Forbes' list but based on our descriptive statics of mean wealth of billionaires by the level of education (see Table 3), they are not outliers.

However, it is hard to conclude that the level of education is not one of the major determinants of billionaires' wealth because there is a trend of getting a higher education among billionaires (Forbes, 1999 2013). Ashenfelter and Mooney (1968) find that professionals having a higher education do not have a significant salary differences in the present but tend to have higher salary in the long-run. Therefore, we examine whether having the higher education (master's degree and higher) is associated with billionaires to persistently increasing their wealth in the future.

In this paper we examine the performance of billionaires, self-employed principals and aim to find out what is the effect of education stemming from the signaling theory. Based on the foregoing, we state our second hypothesis in a null form:

\section{H0 2: Billionaires' wealth is not associated with the level of education.}

\section{Methodology and Sample Selection}

\subsection{Methodology}

The economic development of a country is one of the important social influences in growing wealth of their members (Aidis et al., 2008). According to Table 1, U.S. has about the same GDP per capita (GDPEE) as Sweden and Austria during the sample period but in terms of the number of billionaire year observations, U.S. exceeds those two countries (U.S. has 4,831 billionaire year observations whereas 48 for Austria and 124 for Sweden). Also, Germany has about the same GDP per capita (GDPEE) as France during the sample period but Germany has over three times more billionaires listed in Forbes than France (Germany has 757 billionaire year observations whereas France has 217). Kreiser et al. (2010) use GDP as an institutional variable that measures the economic structure and development of a country and find GDP per capita is one of the indicators of predicting the risk taking and proactiveness of small to medium sized enterprises in different country: as GDP increases, the level of risk taking decreases.

Prior researches have used law and order tradition as one of the important factors in measuring the institutional condition (La Porta et al., 1997, Shlapentokh, 2013). Baumol (1990) claims that the degree of existing legal and political development influences the entrepreneurs' wealth creating activities: in countries with stable and sound legal and political development, members tend to create wealth from productive market activities than from unproductive political and legal activities such as lobbying. Tonoyan et al. (2010) find that if the legal system is not stable and immature, the entrepreneurs are more likely to engage in illegal activities (i.e., corruption, bribing and etc.). Aidis et al. (2008) find that the institutional environment affects the entrepreneurial activities: a weak institutional environment discourages the entrepreneurial activities.

We formulate following models to examine the impact of six components of culture, economic development, institutional condition and individual ability on wealth creating of billionaires and the degree of persistence of their wealth. Model 1 is to test whether the wealth of billionaires is related to six components of culture, economic development, institutional condition, and getting higher education. And Model 2 and 3 are to test whether the 
persistence of wealth of billionaires is related to six components of culture, economic development, institutional condition, and getting higher education.

$$
\begin{aligned}
& \text { WORTH }_{\mathrm{i}, \mathrm{t}}=\alpha_{0}+\alpha_{1} \text { AVOID }_{\mathrm{i}, \mathrm{t}-1}+\alpha_{2} \text { PDIST }_{\mathrm{i}, \mathrm{t}-1}+\alpha_{3} \text { INDIV }_{\mathrm{i}, \mathrm{t}-1}+\alpha_{4} \text { MASCU }_{\mathrm{i}, \mathrm{t}-1}+\alpha_{5} \mathrm{LONGT}_{\mathrm{i}, \mathrm{t}-1}+\alpha_{6} \text { INDUL }_{\mathrm{i}, \mathrm{t}-1} \\
& +\alpha_{7} \text { LAWOT }_{\mathrm{i}, \mathrm{t}-1}+\alpha_{8} \text { CORIG }_{\mathrm{i}, \mathrm{t}-\mathrm{1}}+\alpha_{9} \mathrm{GDPEE}_{\mathrm{i}, \mathrm{t}-1}+\alpha_{10} \mathrm{AGE}_{\mathrm{i}, \mathrm{t}}+\alpha_{11} \text { SELFMADE }_{\mathrm{i}, \mathrm{t}}+\alpha_{12} \mathrm{HIGHED}_{\mathrm{i}, \mathrm{t}} \\
& + \text { INDUSTRY CONTROL }+\varepsilon_{\mathrm{i}, \mathrm{t}} \\
& \text { M3WORTH }_{\mathrm{i}, \mathrm{t}+1}=\alpha_{0}+\alpha_{1} \text { AVOID }_{\mathrm{i}, \mathrm{t}-1}+\alpha_{2} \text { PDIST }_{\mathrm{i}, \mathrm{t}-1}+\alpha_{3} \text { INDIV }_{\mathrm{i}, \mathrm{t}-1}+\alpha_{4} \text { MASCU }_{\mathrm{i}, \mathrm{t}-1}+\alpha_{5} \text { LONGT }_{\mathrm{i}, \mathrm{t}-1} \\
& +\alpha_{6} \text { INDUL }_{i, t-1}+\alpha_{7} \text { LAWOT }_{i, t-1}+\alpha_{8} \text { CORIG }_{i, t-1}+\alpha_{9} \text { GDPEE }_{i, t-1}+\alpha_{10} \text { AGE }_{i, t}
\end{aligned}
$$

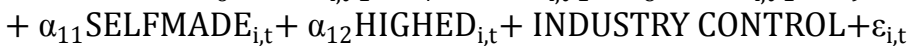

$$
\begin{aligned}
& \text { V3WORTH } \mathrm{i}_{\mathrm{i}, \mathrm{t}+1}=\alpha_{0}+\alpha_{1} \text { AVOID }_{\mathrm{i}, \mathrm{t}-1}+\alpha_{2} \text { PDIST }_{\mathrm{i}, \mathrm{t}-1}+\alpha_{3} \text { INDIV }_{\mathrm{i}, \mathrm{t}-1}+\alpha_{4} \text { MASCU }_{\mathrm{i}, \mathrm{t}-1}+\alpha_{5} \text { LONGT }_{\mathrm{i}, \mathrm{t}-1} \\
& +\alpha_{6} \text { INDUL }_{i, t-1}+\alpha_{7} \text { LAWOT }_{i, t-1}+\alpha_{8} \text { CORIG }_{i, t-1}+\alpha_{9} \text { GDPEE }_{i, t-1}+\alpha_{10} \text { AGE }_{i, t}
\end{aligned}
$$

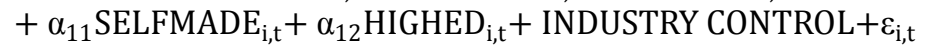

Where, WORTH=wealth of individual billionaires (in billions of U.S. dollars), M3WORTH=mean of 3 year ahead wealth of individual billionaires, V3WORTH=variance of 3 year ahead wealth of individual billionaires, AVOID=risk and uncertainty avoidance, PDIST=power distance, INDIV=individuality, MASCU=masculinity, LONGT=long-term orientation, INDUL=indulgence, LAWOT=law and order tradition, CORIG=corruption in government, GDPEE=GDP per capita, HIGHED=higher education dummy (master's degree or Ph.D.), SELFMADE=self-made dummy, $A G E=$ age of individual billionaire, INDUSTRY $=2$ digit GICS industry classification codes.

\subsection{Data and Sample Selection}

We use Forbes' annual publication of "The World's Billionaires List" to collect data on individual billionaires such as their wealth in U.S. dollar (WORTH: the value of individuals' assets - including stakes in public and private companies, real estate yachts, art and cash - and account for debt expressed in billions of U.S. dollars), age (AGE), nationality (used to link with culture variables), level of education (HIGHED=1 if billionaires have master's degree or Ph.D., $=0$ otherwise), whether the wealth is self-made or inherited (SELFMADE=1 if billionaires' wealth is self-made, $=0$ otherwise) and the source of wealth (used to define industry).

Then based on the nationality of the billionaires defined by Forbes, we collect six culture variables; risk and uncertainty avoidance (AVOID), power distance (PDIST), individuality (INDIV), masculinity (MASCU), long-term

orientation versus short-term (LONGT), and indulgence versus restrain (INDUL) from http://www.geert-hofstede.com/hofstede_dimensions.php as of March, 2013 (Hofstede, 2010). Law and order tradition scores (LAWOT), as well as corruption scores (CORIG) are collected from the International Country Risk Guide as of February 2013. We obtain each country-year's GDP per capita (GDPEE) from the World Bank's World Development Indicators database as of February, 2013.

Our sample covers years from 1999 to 2013. After excluding individual observations with missing variables, we use 11,783 billionaire year observations in our regression models. We winsorize our variables values below and above the second $\left(99^{\text {th }}\right)$ percentile respectively. 
Table 1. Mean of key variables by country during sample period (1999-2013)

\begin{tabular}{|c|c|c|c|c|c|c|c|c|c|}
\hline Country (N) & WORTH & VOID & PDIST & INDIV & MASC & LONC & INDUL & GDPEE & $\begin{array}{l}\text { HIGH } \\
\text { ED }\end{array}$ \\
\hline Argentina (31) & 1.929 & 0.860 & 0.490 & 0.460 & 0.560 & 0.204 & 0.618 & 0.008 & 0.065 \\
\hline Australia (140) & 2.863 & 0.510 & 0.360 & 0.900 & 0.610 & 0.212 & 0.714 & 0.045 & 0.064 \\
\hline Austria (48) & 3.419 & 0.700 & 0.110 & 0.550 & 0.790 & 0.605 & 0.627 & 0.044 & 0.667 \\
\hline Belgium (24) & 2.408 & 0.940 & 0.650 & 0.750 & 0.540 & 0.819 & 0.567 & 0.040 & 0 \\
\hline Brazil (245) & 3.690 & 0.760 & 0.690 & 0.380 & 0.490 & 0.438 & 0.592 & 0.009 & 0.147 \\
\hline Canada (304) & 3.328 & 0.480 & 0.390 & 0.800 & 0.520 & 0.360 & 0.683 & 0.038 & 0.332 \\
\hline Switzerland (163) & 3.671 & 0.580 & 0.340 & 0.680 & 0.700 & 0.736 & 0.661 & 0.052 & 0.577 \\
\hline Chile (61) & 4.601 & 0.860 & 0.630 & 0.230 & 0.280 & 0.310 & 0.680 & 0.009 & 0.361 \\
\hline China (502) & 2.139 & 0.300 & 0.800 & 0.200 & 0.660 & 0.874 & 0.237 & 0.005 & 0.321 \\
\hline Czech Republic (17) & 4.794 & 0.740 & 0.570 & 0.580 & 0.570 & 0.700 & 0.295 & 0.019 & 0.235 \\
\hline Germany (757) & 4.292 & 0.650 & 0.350 & 0.670 & 0.660 & 0.829 & 0.404 & 0.035 & 0.301 \\
\hline Denmark (38) & 3.229 & 0.230 & 0.180 & 0.740 & 0.160 & 0.348 & 0.696 & 0.047 & 0.553 \\
\hline Egypt (43) & 3.563 & 0.680 & 0.800 & 0.380 & 0.520 & 0.068 & 0.042 & 0.002 & 0.395 \\
\hline Spain (180) & 3.369 & 0.860 & 0.570 & 0.510 & 0.420 & 0.476 & 0.435 & 0.028 & 0.167 \\
\hline Finland (4) & 2.525 & 0.590 & 0.330 & 0.630 & 0.260 & 0.383 & 0.574 & 0.048 & 1.000 \\
\hline France (217) & 5.997 & 0.860 & 0.680 & 0.710 & 0.430 & 0.635 & 0.478 & 0.033 & 0.194 \\
\hline United Kingdom (362) & 2.691 & 0.350 & 0.350 & 0.890 & 0.660 & 0.511 & 0.694 & 0.037 & 0.202 \\
\hline Greece (31) & 3.687 & 1.120 & 0.600 & 0.350 & 0.570 & 0.453 & 0.496 & 0.021 & 0.742 \\
\hline Hong Kong (321) & 4.553 & 0.290 & 0.680 & 0.250 & 0.570 & 0.610 & 0.170 & 0.030 & 0.315 \\
\hline Indonesia ( 90) & 0 & 0.480 & 0.780 & 0.140 & 0.460 & 0.620 & 0.377 & 0.003 & 0.133 \\
\hline India (404) & 4.3 & 0.400 & 0.770 & 0.480 & 0.560 & 0.509 & 0.261 & 0.001 & 0.371 \\
\hline Ireland (57) & 2.833 & 0.350 & 0.280 & 0.700 & 0.680 & 0.244 & 0.650 & 0.047 & 0.298 \\
\hline Iceland (8) & 2.013 & 0.500 & 0.300 & 0.600 & 0.100 & 0.280 & 0.667 & 0.055 & 0 \\
\hline Italy(196) & 4.314 & 0.750 & 0.500 & 0.760 & 0.700 & 0.615 & 0.297 & 0.030 & 0.184 \\
\hline Japan (392) & 2.891 & 0.920 & 0.540 & 0.460 & 0.950 & 0.879 & 0.417 & 0.037 & 0.138 \\
\hline Kore & 2.463 & 0.850 & 0.600 & 0.180 & 0.390 & 1.000 & 0.295 & 0.020 & 0.417 \\
\hline Mexico (169) & .719 & 0.820 & 0.810 & 0.300 & 0.690 & 0.242 & 0.973 & 0.008 & 0.213 \\
\hline Mala & 3.8 & 0.360 & 1.040 & 0.260 & 0.500 & 0.408 & 0.571 & 0.007 & 0.126 \\
\hline Nigeri & 7.670 & 0.540 & 0.770 & 0.200 & 0.460 & 0.128 & 0.839 & 0.001 & 0.300 \\
\hline Netherlands (62) & 3.037 & 0.530 & 0.380 & 0.800 & 0.140 & 0.670 & 0.683 & 0.041 & 0.581 \\
\hline Norway (47) & 2.545 & 0.500 & 0.310 & 0.690 & 0.080 & 0.345 & 0.551 & 0.077 & 0 \\
\hline New Zealand (25) & 2.930 & 0.490 & 0.220 & 0.790 & 0.580 & 0.327 & 0.746 & 0.029 & 0.040 \\
\hline Peru (12) & 2.400 & 0.870 & 0.640 & 0.160 & 0.420 & 0.252 & 0.462 & 0.006 & 0.167 \\
\hline Philippines (55) & 2.492 & 0.440 & 0.940 & 0.320 & 0.640 & 0.275 & 0.420 & 0.002 & 0.018 \\
\hline Poland (34) & 1.882 & 0.930 & 0.680 & 0.600 & 0.640 & 0.378 & 0.292 & 0.012 & 0.412 \\
\hline Portugal (32) & 2.238 & 1.040 & 0.630 & 0.270 & 0.310 & 0.282 & 0.333 & 0.019 & 0.375 \\
\hline Russia (662) & 4.547 & 0.950 & 0.930 & 0.390 & 0.360 & 0.814 & 0.199 & 0.010 & 0.215 \\
\hline Saudi Arabia (136) & 5.821 & 0.680 & 0.800 & 0.380 & 0.520 & 0.355 & 0.522 & 0.014 & 0.456 \\
\hline Singapore (74) & 2.793 & 0.080 & 0.740 & 0.200 & 0.480 & 0.715 & 0.455 & 0.031 & 0.135 \\
\hline Sweden (124) & 7.574 & 0.290 & 0.310 & 0.710 & 0.050 & 0.529 & 0.777 & 0.044 & 0.339 \\
\hline Thailand (47) & 3.448 & 0.640 & 0.640 & 0.200 & 0.340 & 0.317 & 0.451 & 0.004 & 0.191 \\
\hline Turkey (278) & 1.773 & 0.850 & 0.660 & 0.370 & 0.450 & 0.456 & 0.491 & 0.009 & 0.205 \\
\hline United States $(4,831)$ & 3.438 & 0.460 & 0.400 & 0.910 & 0.620 & 0.257 & 0.681 & 0.044 & 0.380 \\
\hline Venezuela (31) & 4.171 & 0.760 & 0.810 & 0.120 & 0.730 & 0.156 & 1.000 & 0.007 & 0.484 \\
\hline South Africa (45) & 3.540 & 0.490 & 0.490 & 0.650 & 0.630 & 0.340 & 0.630 & 0.006 & 0.644 \\
\hline
\end{tabular}

Notes: WORTH: value of individuals' assets-including stakes in public and private companies, real estate, yachts, art and cash-and account for debt (in billions of U.S. dollars) (Forbes, 2013). AVOID: Hofestede's risk and uncertainty avoidance/100. PDIST: Hofestede's power distance/100. INDIV: Hofestede's individuality/100. MASCU: Hofestede's masculinity/100. LONGT: Hofestede's long-term orientation (versus short-term orientation). INDUL: Hofestede's indulgence (versus restrain). LAWOT: law and order tradition. CORIG: corruption in government. GDPEE: GDP per capita (current U.S. dollars scaled to millions). HIGHED $=1$ if billionaires have master's degree. and/or Ph.D., $=0$ otherwise. SELFMADE $=1$ if wealth is self-made, $=0$ otherwise as disclosed in Forbes list. AGE: age of individual billionaire as disclosed in Forbes list. 
We report the means of key variables by country in Table 1. U.S. has the most number of billionaire observations (4,831 billionaire year observations) but in terms of mean wealth of billionaires (WORTH), Nigeria has the highest average WORTH (7.67) even though it has only 10 billionaire year observations. Greece has the highest mean risk and uncertainty avoidance (AVOID) (1.120), whereas Singapore has the lowest (0.080). Malaysia has the highest mean power distance (PDIST) (1.040) whereas Austria has the lowest (0.110). U.S. shows high tendency for individuality (INDIV) (0.910) whereas Venezuela is on the other side of the spectrum (0.120). Japan shows tendency for masculinity (MASCU) (0.950) whereas Sweden shows tendency for femininity $(0.050)$. Korea has a culture that is long-term orientated (LONGT) (1.000) whereas Egypt has a culture that is short-term oriented (0.068). In terms of indulgence (INDUL), Venezuela has the highest mean (1.000) and Egypt has the lowest (0.042). The country with the highest mean GDP per capital is Norway (0.077) and the lowest are India and Nigeria (0.001). All billionaires from Finland have master's degree and higher $(\mathrm{HIGHED}=1)$ whereas, none of billionaires from Belgium, Iceland, and Norway has master's degree and higher (HIGHED).

Table 2. Descriptive statistics of key variables

\begin{tabular}{|c|c|c|c|c|c|c|c|}
\hline & Min & Q1 & Median & Mean & Q3 & Max & Std. Dev \\
\hline WORTH & 1 & 1.400 & 2.100 & 3.610 & 3.800 & 73.00 & 4.300 \\
\hline AVOID & 0.080 & 0.460 & 0.460 & 0.562 & 0.690 & 1.120 & 0.201 \\
\hline PDIST & 0.110 & 0.400 & 0.400 & 0.520 & 0.680 & 1.040 & 0.196 \\
\hline INDIV & 0.080 & 0.390 & 0.710 & 0.659 & 0.910 & 0.910 & 0.267 \\
\hline MASCU & 0.050 & 0.520 & 0.620 & 0.579 & 0.620 & 0.950 & 0.137 \\
\hline LONGT & 0.068 & 0.257 & 0.360 & 0.468 & 0.670 & 1 & 0.245 \\
\hline INDUL & 0 & 0.404 & 0.681 & 0.542 & 0.681 & 1 & 0.193 \\
\hline LAWOT & 0.170 & 0.750 & 0.830 & 0.790 & 0.830 & 1 & 0.150 \\
\hline CORIG & 0.170 & 0.420 & 0.670 & 0.600 & 0.670 & 1 & 0.170 \\
\hline GDPEE & 0.0004 & 0.016 & 0.037 & 0.032 & 0.046 & 0.186 & 0.017 \\
\hline AGE & 34 & 53 & 63 & 63.240 & 73 & 99 & 13.550 \\
\hline SELFMADE & 0 & 0 & 1 & 0.687 & 1 & 1 & 0.463 \\
\hline HIGHED & 0 & 0 & 0 & 0.307 & 1 & 1 & 0.461 \\
\hline
\end{tabular}

Notes: $\mathrm{N}=11,783$ observations. WORTH: value of individuals' assets-including stakes in public and private companies, real estate, yachts, art and cash-and account for debt (in billions of U.S. dollars) (Forbes, 2013). AVOID: Hofestede's risk and uncertainty avoidance/100. PDIST: Hofestede's power distance/100. INDIV: Hofestede's individuality/100. MASCU: Hofestede's masculinity/100. LONGT: Hofestede's long-term orientation (versus short-term orientation). INDUL: Hofestede's indulgence (versus restrain). LAWOT: law and order tradition. CORIG: corruption in government. GDPEE: GDP per capita (current U.S. dollars scaled to millions). HIGHED $=1$ if billionaires have master's degree. and/or Ph.D., $=0$ otherwise. SELFMADE $=1$ if wealth is self-made, $=0$ otherwise as disclosed in Forbes list. AGE: age of individual billionaire as disclosed in Forbes list.

In Table 2, we provide the descriptive statistics of Hofstede's six dimensions of culture variables (AVOID, PDIST, INDIV, MASCU, LONGT, and INDUL), economic variable (GDPEE), law and order tradition (LAWOT and CORIG), wealth of billionaires (WORTH), higher education (HIGHED), age of billionaires (AGE), and source of wealth (SELFMADE).

Table 3. Descriptive statistics of WORTH (in billions of U.S. dollars) by the level of education

\begin{tabular}{|c|c|c|c|c|c|c|c|}
\hline & WOR & in $b$ & of U.S. & llars & & & \\
\hline & Min & Q1 & Median & Mean & Q3 & Max & Std. Dev \\
\hline Less than high school diploma & 1.0 & 1.7 & 3.10 & 6.96 & 10.0 & 57.0 & 8.03 \\
\hline With high school diploma & 1.0 & 1.5 & 2.50 & 4.32 & 4.6 & 67.0 & 5.39 \\
\hline With bachelor's degree & 1.0 & 1.5 & 2.10 & 3.40 & 3.6 & 73.0 & 3.77 \\
\hline With master's degree & 1.0 & 1.5 & 2.20 & 3.66 & 3.8 & 53.5 & 4.27 \\
\hline With Ph.D. & 1.0 & 1.5 & 2.20 & 3.58 & 3.8 & 26.1 & 3.84 \\
\hline
\end{tabular}

In Table 3, we provide descriptive statistics of WORTH by level of education. Out of 11,783 observations, about 4\% have less than high school diploma, 13\% have high school diploma, $49 \%$ have a bachelor's degree, $23 \%$ have a master's degree, and $11 \%$ have a Ph.D. Billionaires with less than high school diploma have highest median (\$3.1 billion) and mean ( $\$ 6.96$ billion) wealth, which is highest compared to other education groups. 


\section{Results}

In Table 4, we provide the correlation matrix for key variables. Uncertainty avoidance (AVOID) (Pearson: 0.0337, Spearman: 0.0581) and long-term orientation (LONGT) (Pearson: 0.0148, Spearman: 0.0550) have significantly positive correlations with the wealth of billionaire (WORTH) in both Pearson and Spearman correlations. Power distance (PDIST) has a significantly positive correlation in Pearson (0.0313) and a significantly negative correlation in Spearman (-0.0306). Masculinity (MSCU) (Pearson: -0.0698, Spearman: -0.0237) and indulgence (INDUL) (Pearson: -0.0168, Spearman: -0.0304) have significantly negative correlations with the wealth of billionaire (WORTH) in both Pearson and Spearman correlations. HIGHED has a significantly positive relation with WORTH in Spearman correlation (0.0290).

Table 4. Pearson (upper) and Spearman (lower) correlation matrix

\begin{tabular}{lllllllll}
\hline & WORTH & AVOID & PDIST & INDIV & MASCU & LONGT & INDUL & HIGHED \\
\hline WORTH & 1.0000 & 0.0337 & 0.0313 & 0.0010 & -0.0698 & 0.0148 & -0.0168 & 0.0056 \\
& & $(0.0002)$ & $(0.0006)$ & $(0.9170)$ & $(<.0001)$ & $(0.1067)$ & $(0.0678)$ & $(0.5402)$ \\
AVOID & 0.0581 & 1.0000 & 0.3288 & -0.3644 & -0.1468 & 0.3797 & -0.2922 & -0.1005 \\
& $(<.0001)$ & & $(<.0001)$ & $(<.0001)$ & $(<.0001)$ & $(<.0001)$ & $(<.0001)$ & $(<.0001)$ \\
PDIST & -0.0306 & 0.2055 & 1.0000 & -0.7794 & -0.2776 & 0.4157 & -0.6472 & -0.0890 \\
& $(0.0008)$ & $(<.0001)$ & & $(<.0001)$ & $(<.0001)$ & $(<.0001)$ & $(<.0001)$ & $(<.0001)$ \\
INDIV & -0.0297 & -0.3137 & -0.6146 & 1.0000 & 0.2469 & -0.6433 & 0.6801 & 0.1066 \\
& $(0.0011)$ & $(<.0001)$ & $(<.0001)$ & & $(<.0001)$ & $(<.0001)$ & $(<.0001)$ & $(<.0001)$ \\
MASCU & -0.0237 & -0.2347 & -0.3482 & 0.2441 & 1.0000 & -0.0324 & 0.1464 & 0.0289 \\
& $(0.0096)$ & $(<.0001)$ & $(<.0001)$ & $(<.0001)$ & & $(0.0004)$ & $(<.0001)$ & $(0.0015)$ \\
LONGT & 0.0550 & 0.2809 & 0.2610 & -0.7134 & -0.0137 & 1.0000 & -0.7461 & -0.0831 \\
& $(<.0001)$ & $(<.0001)$ & $(<.0001)$ & $(<.0001)$ & $(0.1354)$ & & $(<.0001)$ & $(<.0001)$ \\
INDUL & -0.0304 & -0.2692 & -0.6028 & 0.6881 & 0.1383 & -0.71880 & 1.0000 & 0.0703 \\
& $(0.0010)$ & $(<.0001)$ & $(<.0001)$ & $(<.0001)$ & $(<.0001)$ & $(<.0001)$ & & $(<.0001)$ \\
HIGHED & 0.0290 & -0.0921 & -0.0761 & 0.1189 & 0.0503 & -0.0855 & 0.0634 & 1.0000 \\
& $(0.0014)$ & $(<.0001)$ & $(<.0001)$ & $(<.0001)$ & $(<.0001)$ & $(<.0001)$ & $(<.0001)$ & \\
\hline
\end{tabular}

Notes: WORTH: value of individuals' assets-including stakes in public and private companies, real estate, yachts, art and cash-and account for debt (in billions of U.S. dollars) (Forbes, 2013). AVOID: Hofestede's risk and uncertainty avoidance/100. PDIST: Hofestede's power distance/100. INDIV: Hofestede's individuality/100. MASCU: Hofestede's masculinity/100. LONGT: Hofestede's long-term orientation (versus short-term orientation). INDUL: Hofestede's indulgence (versus restrain). HIGHED $=1$ if billionaires have master's degree and/or Ph.D., $=0$ otherwise.

Table 5, provides main regression analysis which is to test our Model 1,2, and 3. To avoid serial correlation, we use Fama-MacBeth (1973) regressions rather than pooled regressions. 
Table 5. Fama-MacBeth (1973) regression models

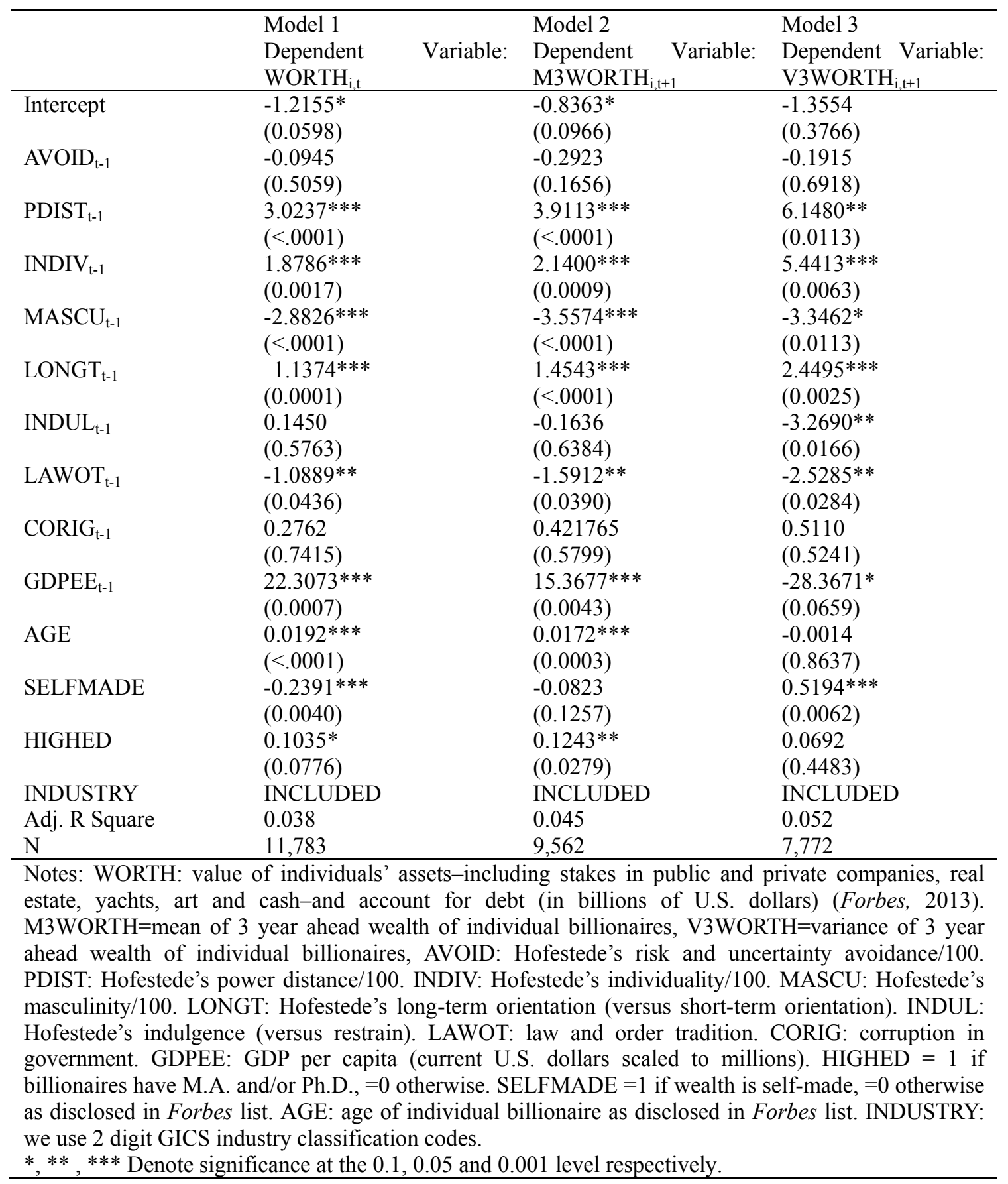

In Model 1, we examine the impact of six components of Hofstede's culture, economic development, institutional and education variables on increasing a one year ahead wealth of billionaires. We find that billionaires from more power distanced $\left(\right.$ PDIST $\left._{t-1}\right)$ (3.0237 with $\operatorname{Pr}>|t|$ at $<.0001$ significance), more individuality (INDIV I-1 $)(1.8786$ with $\operatorname{Pr}>|t|$ at 0.0017 significance), less masculinity $\left(\operatorname{MASCU}_{t-1}\right)(-2.8826$ with $\operatorname{Pr}>|t|$ at $<.0001$ significance), and more long-term orientation $\left(\mathrm{LONGT}_{\mathrm{t}-1}\right)(1.1374$ with $\mathrm{Pr}>|\mathrm{t}|$ at 0.0001 significance) cultures are more likely to increase their wealth. LAWOT $_{t-1}$ is negatively related (-1.0889 with $\operatorname{Pr}>|t|$ at 0.0436 significance) whereas economic development variable GDPEE $_{\mathrm{t}-1}$ is positively related to WORTH $(22.3073$ with $\operatorname{Pr}>|\mathrm{t}|$ at 0.0007 significance). We find that it is hard for self-made billionaires to increase their wealth compared to inherited or endowed billionaires (SELFMADE: -0.2391 with $\operatorname{Pr}>|t|$ at 0.0040 significance). We also find that billionaires with higher education 
(HIGHED) are more likely to increase their wealth than those without master's degree or Ph.D. (0.1035 with $\operatorname{Pr}>|\mathrm{t}|$ at 0.0776 significance). To summarize, billionaires in culture with high power distanced (i.e., those who already have power can sustain their power without distributing it among members), that value individual achievement, with more emphasis on relationship, and long- term orientation are more likely to accumulate their wealth. The economic infrastructure is also one of the major factors that encourage billionaires to increase their wealth. Billionaires are more likely to increase their wealth by getting higher education: master's degree or Ph.D.

In Model 2, we examine the impact of six components of Hofstede's culture, economic development, institutional and education variables on changes in future wealth of billionaires (M3WORTH). We find that billionaires from more power distanced ( $\mathrm{PDIST}_{\mathrm{t}-1}$ ) (3.9113 with $\mathrm{Pr}>|\mathrm{t}|$ at $<.0001$ significance), more individuality (INDIV $\left.\mathrm{t}_{\mathrm{t}-1}\right)(2.1400$ with $\operatorname{Pr}>|t|$ at 0.0009 significance), less masculinity $\left(\mathrm{MASCU}_{\mathrm{t}-1}\right)(-3.5574$ with $\operatorname{Pr}>|\mathrm{t}|$ at $<.0001$ significance), and more long-term orientation ( $\left.\mathrm{LONGT}_{\mathrm{t}-1}\right)(1.4543$ with $\mathrm{Pr}>|\mathrm{t}|$ at $<.0001$ significance) cultures are more likely to increase their wealth more persistently in the next 3 years. $\mathrm{LAWOT}_{\mathrm{t}-1}$ is negatively related $(-1.5912 \mathrm{with} \operatorname{Pr}>|\mathrm{t}|$ at 0.0390 significance) whereas economic development variable GDPEE $_{t-1}$ is positively related to M3WORTH (15.3677 with $\operatorname{Pr}>|t|$ at 0.0043 significance). We also find that billionaires with the higher education (HIGHED) are more likely to increase their future wealth for a longer period than those without master's or Ph.D. (0.1243 with $\operatorname{Pr}>|t|$ at 0.0279 significance). To summarize Model 2 findings, billionaires in cultures with high power distanced, more individuality, more femininity, and long-term orientation are more likely to accumulate wealth that sustain in the future. The economic infrastructure is also one of the major factors that encourage billionaires to have persistent future wealth. Billionaires are more likely to have persistent wealth by getting higher education: master's degree or Ph.D.

In Model 3, we use whether different aspects of culture, law and order tradition, economic development, and level of education helps explain volatility of billionaires' future wealth. We find that billionaires from more power distanced $\left(\right.$ PDIST $\left._{t-1}\right)\left(6.1480\right.$ with $\operatorname{Pr}>|t|$ at 0.0113 significance), more individuality $\left(\operatorname{INDIV}_{\mathrm{t}-1}\right)(5.4413$ with $\operatorname{Pr}>|\mathrm{t}|$ at 0.0063 significance), less masculinity ( $\left.\mathrm{MASCU}_{\mathrm{t}-1}\right)(-3.3462$ with $\operatorname{Pr}>|\mathrm{t}|$ at 0.0113 significance), more long-term orientation $\left(\mathrm{LONGT}_{\mathrm{t}-1}\right)\left(2.4495\right.$ with $\operatorname{Pr}>|\mathrm{t}|$ at 0.0025 significance), and less indulgence (INDUL $\left.\mathrm{t}_{\mathrm{t}-1}\right)(-3.2690$ with $\operatorname{Pr}>|\mathrm{t}|$ at 0.0166 significance) cultures are more likely to increase volatility of billionaires' future wealth. LAWOT $_{t-1}$ is negatively related $\left(-2.5285\right.$ with $\operatorname{Pr}>|t|$ at 0.0284 significance) and economic development variable GDPEE $_{t-1}$ is negatively related to V3WORTH (-28.3671 with $\operatorname{Pr}>|\mathrm{t}|$ at 0.0659 significance). We also find that self-made billionaires (SELFMADE) are more likely to have volatile future wealth than billionaires with inherited or endowed wealth ( 0.5194 with $\operatorname{Pr}>|t|$ at 0.0062 significance). To summarize Model 3 findings, billionaires in cultures with the high power distanced, more individuality, more femininity, long-term orientation, and less indulgence are more likely to have volatility in their future wealth. Billionaires from less economic developed countries tend to have more volatility in their future wealth. Also self-made billionaires tend to have more volatility in their wealth in the future compared to inherited or endowed billionaires.

\section{Summary and Conclusion}

Prior research shows that the culture is one of the important social forces that help their members to create and increase their wealth (Muller and Thomas, 2001, Kreiser et al., 2010). We use a natural setting to find answers to one of the interesting questions that capitalism has been posing: are billionaires born or bred. We find that billionaires are bred.

The roles of billionaires in our society have become more influential and important. Asides from participating in various charitable activities, they create jobs through entrepreneurial activities (Pincock, 2003, Larkin, 2006). We expect our findings can be used to improve social infrastructure to increase wealth of individuals and eventually play a role as an incubator to foster prospective billionaires.

We find that six components of Hofsted's culture variables play a different role in increasing wealth of billionaire that sustain in the future. Billionaires from high power distanced cultures tend to increase and maintain their wealth in the future. And individuality and femininity cultures encourage billionaires to create and increase and sustain their wealth. Long-term oriented cultures motivate their members to put more emphasis on future performance and endure to achieve their goals in the long run. As a result, culture provides a good infrastructure to nurture billionaires. The economic environment is also one of the important factors in determining billionaires' wealth. Besides cultural and economic infrastructure, getting higher education is also one of the important factors that increases and sustains billionaires' wealth in the future. 


\section{References}

Aidis, R., Estrin S., \& Mickiewicz T. (2008). Institutions and entrepreneurship development in Russia: A comparative perspective. Journal of Business Venture 23, 656-672. http://dx.doi.org/10.1016/j.jbusvent.2008.01.005

Akerlof, G.A. (1970). The market for "Lemons": Quality uncertainty and the market mechanism. Quarterly Journal of Economics, 488-500. http://dx.doi.org/10.2307/1879431

Ashenfelter, O., \& Mooney J. (1968). Graduate education, ability, and earnings. The Review of Economics and Statistics 50(1), 78-86. http://dx.doi.org/10.2307/1927058

Baumol, W. (1990). Entrepreneurship: Productive, unproductive and destructive. Journal of Political Economy $98(5)$, 893-921. http://dx.doi.org/10.1086/261712

Becker, G. (1964). Human Capital. Chicago: Chicago University Press.

Budman, M. (1997). Do universities stifle entrepreneurship? Across the Board 34(7).

Fama, Eugene F., \& MacBeth, James D. (1973). Risk, return, and equilibrium: empirical tests. Journal of Political Economy 81(3), 607-636. http://dx.doi.org/10.1086/260061

Forbes. (1999-2013). The World's Billionaires List. www.forbes.com.

Geletkanycz, M.A. (1997). The salience of 'culture consequences': The effects of culture values on top executive commitment to the status quo. Strategic Management Journal 18, 615-634. http://dx.doi.org/10.1002/(SICI)1097-0266(199709)18:8<615::AID-SMJ889>3.0.CO;2-I

Gutierrez, C., Glassman, C., Landefeld, J., \& Marcuss, R. (2007). Measuring the economy: A primer on GDP and the national income and product accounts. Bureau of Economic Analysis U.S. Department of Commerce. September. www.bea.gov.

Hitt, M.A., Ahlstrom, D., Dacin, M.T., Levitas, E., \& Svobodina, L. (2004). The institutional effects on strategic alliance partner selection in transition economies: China vs Russia. Organization Science 15(2), 173-185. http://dx.doi.org/10.1287/orsc.1030.0045

Hofstede, G. (1980). Culture's Consequences: International Differences in Work Related Values. Sage Publications, Beverly Hills, CA.

Hofstede, G. (2001). Culture's Consequences: Comparing Values, Behaviors, Institutions, and Organizations across Nations. Second Edition. Sage Publications, Thousand Oaks, CA.

Hofstede, G., Hofstede G. J., \& Minkov, M. (2010). Cultures and Organizations: Software of the Mind. Revised and Expanded 3rd Edition. McGraw-Hill.

Kreiser, P., Marino L., Dickson P., \& Weaver K. (2010). Cultural influence on entrepreneurial orientation: The impact of national culture on risk taking and proactiveness in SMEs. Entrepreneurship Theory and Practice September, 959-983. http://dx.doi.org/10.1111/j.1540-6520.2010.00396.x

La Porta, R., Lopez-de-Silanes F., Shleifer A., \& Vishny R. (1997). Legal determinants of external finance. Journal of Finance 52(3), 1131-1150. http://dx.doi.org/10.1111/j.1540-6261.1997.tb02727.x

Larkin, M. (2006). Buffet gift will benefit global health and disease research. http://www.thelancet.com/journals/laninf/article/PIIS1473-3099(06)70534-5/fulltext. 6(August), 468.

McGrath, R., MacMillan I., Yang E., \& Tsai W. (1992). Does culture endure, or is it malleable? Issues for entrepreneurial economic development. Journal of Business Venture 7(6), 441-458. http://dx.doi.org/10.1016/0883-9026(92)90019-N

Mischel, W. (1958). Preference for delayed reinforcement: An experimental study of a cultural observation. The Journal of Abnormal and Social Psychology 56, 57-61. http://dx.doi.org/10.1037/h0041895

Mischel, W., Ebbesen E., \& Raskoff Zeiss A. (1972). Cognitive and attentional mechanisms in delay of gratification. Journal of Personality and Social Psychology 21(2), 204-218. http://dx.doi.org/10.1037/h0032198

Morris, M.H., Duane, L.D., Jeffrey, W.A. (1994). Fostering corporate entrepreneurship: Cross-cultural comparisons of the importance of individualism versus collectivism. Journal of International Business Studies 25(1), 65-89. http://dx.doi.org/10.1057/palgrave.jibs.8490849 
Mueller, S.L. \& Thomas, A.S. (2001). Culture and entrepreneurial potential: A nine country study of locus of control and innovativeness. Journal of Business Venturing 16(1), 51-75. http://dx.doi.org/10.1016/S0883-9026(99)00039-7

Pincock, S. (2003). Microsoft cofounder provides $\$ 100$ million for brain-gene atlas. http://www.thelancet.com/journals/laneur/article/PIIS1474-4422(03)00573-8/fulltext. 2(November), 652.

Shane, S. (1995). Uncertainty avoidance and the preference for innovation championing roles. Journal of International Business Studies 26(1), 47-68. http://dx.doi.org/10.1057/palgrave.jibs.8490165

Shlapentokh, V. (2013). Corruption, the power of state and big business in Soviet and post-Soviet regimes. Communist and Post Communist Studies 46, 147-158. http://dx.doi.org/10.1016/j.postcomstud.2012.12.010

Spence, M. (1973). Job market signaling. The Quarterly Journal of Economics 87(3), 355-374. http://dx.doi.org/10.2307/1882010

Steensma, H. K., Marino, L., \& Weaver, K. M. (2000). Attitudes toward cooperative strategies: A cross-cultural analysis of entrepreneurs, Journal of International Business Studies 31(4), 591-609. http://dx.doi.org/10.1057/palgrave.jibs.8490924

Taras, V., Rowney, J., \& Steel, P. (2009). Half a century of measuring culture: Review of approaches, challenges, and limitations based on the analysis of 121 instruments for quantifying culture, Journal of International Management 15, 357-373. http://dx.doi.org/10.1016/j.intman.2008.08.005

Tonoyan, V., Strohmeyer, R., Habib, M., \& Perlitz, M. (2010). Corruption and entrepreneurship: How formal and informal institutions shape small firm behavior in transition and mature market economies. Entrepreneurship Theory and Practice September, 803-832. http://dx.doi.org/10.1111/j.1540-6520.2010.00394.x

Vance, C., Grove, K., Gale, J., Hess, G. (2012). Would future entrepreneurs be better served by avoiding university business education? Examining the effect of higher education on business student thinking style. Journal of Entrepreneurship Education 15(SI), 127-141.

Wang, C., Wang, P., Lu, Q. (2001). Entrepreneurial intentions and tertiary education. Conference on Technological Entrepreneurship in the Emerging Regions of the New Millennium, June 2001. Singapore.

World Bank. (2013). World Development Indicator. www.data.worldbank.org. 